IRA-International Journal of Applied Sciences ISSN 2455-4499; Vol.05, Issue 01 (2016)

Institute of Research Advances

Pg. no. $1-5$

http://research-advances.org/index.php/IRAJAS

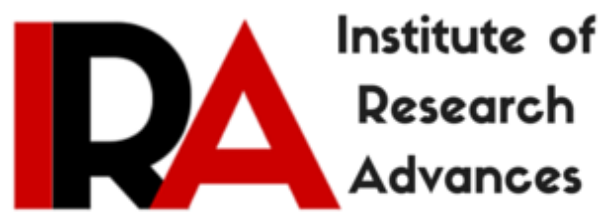

\title{
Study of Gross Alpha and Gross Beta Activities in Rock Samples of Western Ghats in Kanyakumari District
}

\author{
${ }^{1}$ M. Sheela Udhaya Roselin $\&{ }^{2}$ G. Shanthi \\ ${ }^{1,2}$ Department of Physics and Research Centre, \\ Women's Christian College, Nagercoil, TamilNadu, India.
}

Type of Review: Peer Reviewed.

DOI: http://dx.doi.org/10.21013/jas.v5.n1.p1

\section{How to cite this paper:}

Roselin, M., \& Shanthi, G. (2016). Study of Gross Alpha and Gross Beta Activities in Rock Samples of Western Ghats in Kanyakumari District. IRA-International Journal of Applied Sciences (ISSN 2455-4499), 5(1), 1-5. doi:http://dx.doi.org/10.21013/jas.v5.n1.p1

(C) Institute of Research Advances

\section{(cc) BY-NC}

This work is licensed under a Creative Commons Attribution-Non Commercial 4.0 International License subject to proper citation to the publication source of the work.

Disclaimer: The scholarly papers as reviewed and published by the Institute of Research Advances (IRA) are the views and opinions of their respective authors and are not the views or opinions of the IRA. The IRA disclaims of any harm or loss caused due to the published content to any party. 


\section{ABSTRACT}

The present study was carried out to examine the gross alpha and gross beta activities in rock samples in Kanyakumari district. Twenty Four samples were collected from different locations in Western Ghats. The gross alpha and gross beta activities were measured by using zinc sulphide scintillation detector and low beta counter. In this present study the gross alpha activity was maximum at L22 $(1397.85 \mathrm{~Bq} / \mathrm{Kg})$ and minimum at $\mathrm{L} 7(53.76 \mathrm{~Bq} / \mathrm{Kg})$ with an average of $582.44 \mathrm{~Bq} / \mathrm{Kg}$ and the gross beta activity was maximum at L2 $(3815.79 \mathrm{~Bq} / \mathrm{Kg})$ minimum at $\mathrm{L7}(833.33 \mathrm{~Bq} / \mathrm{kg})$ with an average of $2081.51 \mathrm{~Bq} / \mathrm{Kg}$.

Keywords: Gross Alpha, Gross Beta, Western Ghats, Rock

\section{INTRODUCTION}

Radionuclides are found in air, water, soil, rock and everywhere in the Universe. There is no where on earth that one can get away from natural radioactivity [1]. Natural radioactivity arises mainly due to the radioactive nuclides present in different amounts in sediments, water and rocks. Almost all the rocks contain naturally occurring radionuclides such as ${ }^{238} \mathrm{U},{ }^{232} \mathrm{Th}$ and ${ }^{40} \mathrm{~K}$ [2]. Available information indicates that the deposits of monazite on the coastal areas of Kerala and TamilNadu are formed due to the weathering of rocks in Western Ghats [3][8]. Natural Radioactive concentration depends mainly on geological and geographical conditions and appears at different levels in rocks from different geological regions (UNSCEAR 2000) [4].

\section{SAMPLING AND SAMPLE PREPARATION}

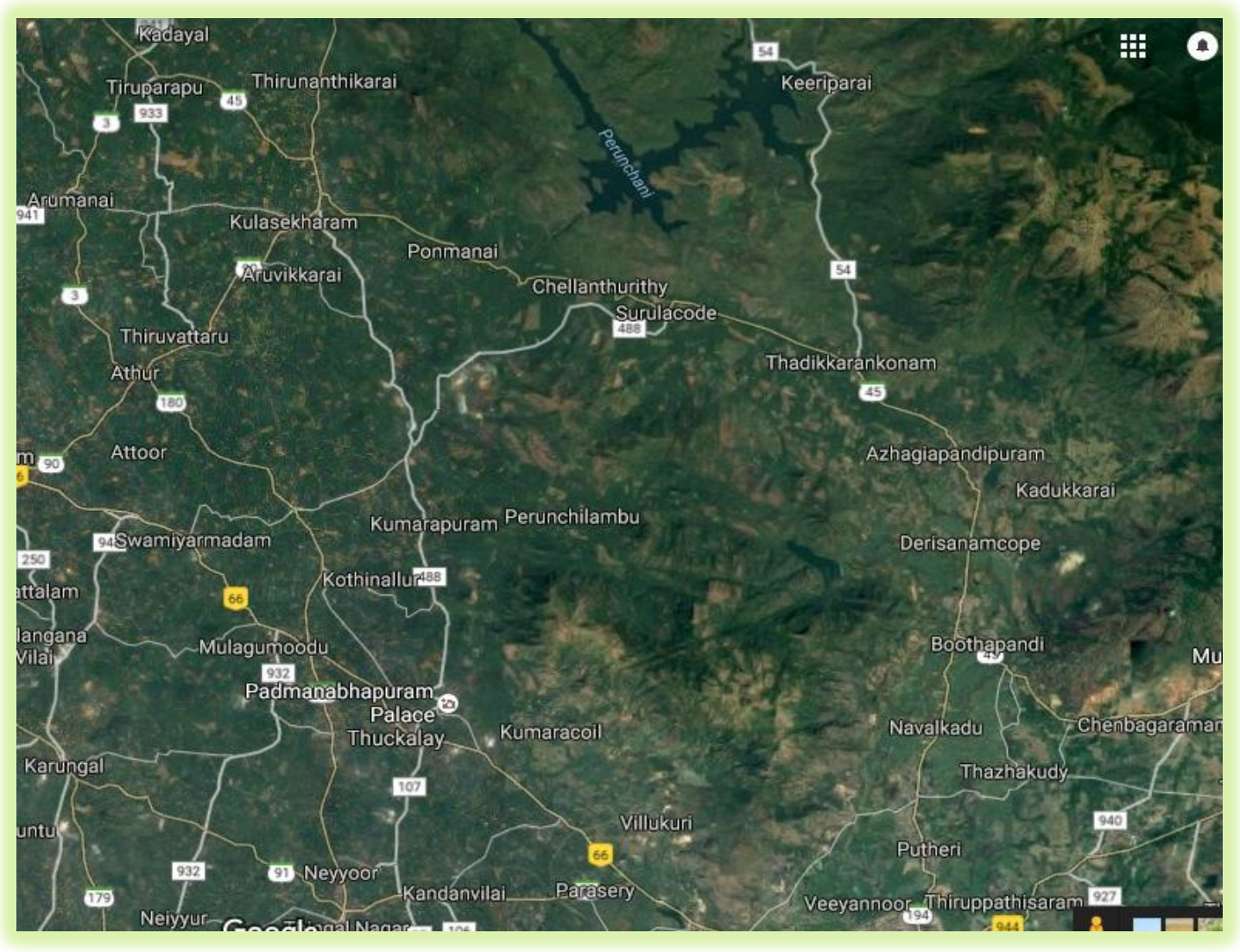

Fig.1 Location of the study area 
For the present study, rock samples were collected from 24 places of Western Ghats in Kanyakumari district. Fig. 1 shows the location of the study area. Some locations were mentioned as the name of the nearby villages.

Basic component of our life support system contains measureable amount of radioactivity. The radio activities due to these components are found out by using different instruments. In this work, the gross alpha and gross beta in the rock samples are measured by using the Zinc Sulphide Scintillation Detector and Low Beta Counter.

\section{ZINC SULPHIDE SCINTILLATION DETECTOR}

An alpha counting system comprises of an alpha probe and counting electronics system includes high voltage supply to probe, a preamplifier, an amplifier, timer and scalar. The counter model SP 647A was used for the measurement. The PMT and crystal are placed $\mathrm{n}$ a light tight steel housing. So as to have very low background and have an efficiency of about $31.07 \%$. The standard source ${ }^{241} \mathrm{Am}$ was used for detector calibrations.

\section{LOW BETA COUNTER}

The Counters consists of two or three G.M counters. The counters have a silver or gold foil window through which the beta particles travels and reach the gas chamber with isopropyl alcohol vapors and ionize the medium. The counter model BCS36A was used for this study. The standard source ${ }^{40} \mathrm{~K}$ was used and the corresponding efficiency of the counter was about $38.16 \%$.

Twenty Four rock samples were collected from the study region to measure gross alpha and gross beta activities. Each sample nearly $1 \mathrm{Kg}$ in weight was washed in distilled water and dried in an oven at nearly $110^{\circ} \mathrm{C}$ to ensure that moisture was completely removed. Then the samples are grinded as a fine powder. About $0.006 \mathrm{gms}$ of powdered samples are spread as a fine layer in a aluminum planchet and its gross alpha and gross beta activity were measured using alpha and beta counter[5]. The samples were counted for $1000 \mathrm{~s}$.

\section{RESULTS AND DISCUSSION}

The results of the gross alpha and gross beta activity of five rock samples are presented in table1.

Table 1: Determination of Gross Alpha and Gross Beta activity of rock samples.

\begin{tabular}{clll}
\hline Sl.No & Sample Location & Gross Alpha $(\mathbf{B q} / \mathbf{K g})$ & Gross Beta $(\mathbf{B q} / \mathbf{K g})$ \\
\hline 1. & $\mathrm{~L}_{1}$ & 1129.03 & 1578.95 \\
2. & $\mathrm{~L}_{2}$ & 806.45 & $\mathbf{3 8 1 5 . 7 9}$ \\
3. & $\mathrm{~L}_{3}$ & 483.87 & 1535.09 \\
4. & $\mathrm{~L}_{4}$ & 215.05 & 1710.53 \\
5. & $\mathrm{~L}_{5}$ & 268.82 & 1491.23 \\
6. & $\mathrm{~L}_{6}$ & 591.40 & 1666.67 \\
7. & $\mathrm{~L}_{7}$ & $\mathbf{5 3 . 7 6}$ & $\mathbf{8 3 3 . 3 3}$ \\
8. & $\mathrm{~L}_{8}$ & 645.17 & 1578.95 \\
9. & $\mathrm{~L}_{9}$ & 322.58 & 877.19 \\
10. & $\mathrm{~L}_{10}$ & 698.92 & 3245.61 \\
11. & $\mathrm{~L}_{11}$ & 913.98 & 1842.11 \\
\hline
\end{tabular}




\begin{tabular}{llll}
\hline 12. & $\mathrm{~L}_{12}$ & 537.63 & 1929.82 \\
13. & $\mathrm{~L}_{13}$ & 107.53 & 1622.81 \\
14. & $\mathrm{~L}_{14}$ & 376.34 & 2149.12 \\
15. & $\mathrm{~L}_{15}$ & 376.34 & 2017.54 \\
16. & $\mathrm{~L}_{16}$ & 645.16 & 2105.26 \\
17. & $\mathrm{~L}_{17}$ & 537.63 & 2938.60 \\
18. & $\mathrm{~L}_{18}$ & 752.69 & 2807.02 \\
19. & $\mathrm{~L}_{19}$ & 1290.32 & 2192.98 \\
20. & $\mathrm{~L}_{20}$ & 967.74 & 2675.44 \\
21. & $\mathrm{~L}_{21}$ & 161.29 & 2456.14 \\
22. & $\mathrm{~L}_{22}$ & $\mathbf{1 3 9 7 . 8 5}$ & 2500.01 \\
23. & $\mathrm{~L}_{23}$ & 430.11 & 2587.72 \\
24. & $\mathrm{~L}_{24}$ & 268.82 & 1798.25 \\
\hline
\end{tabular}

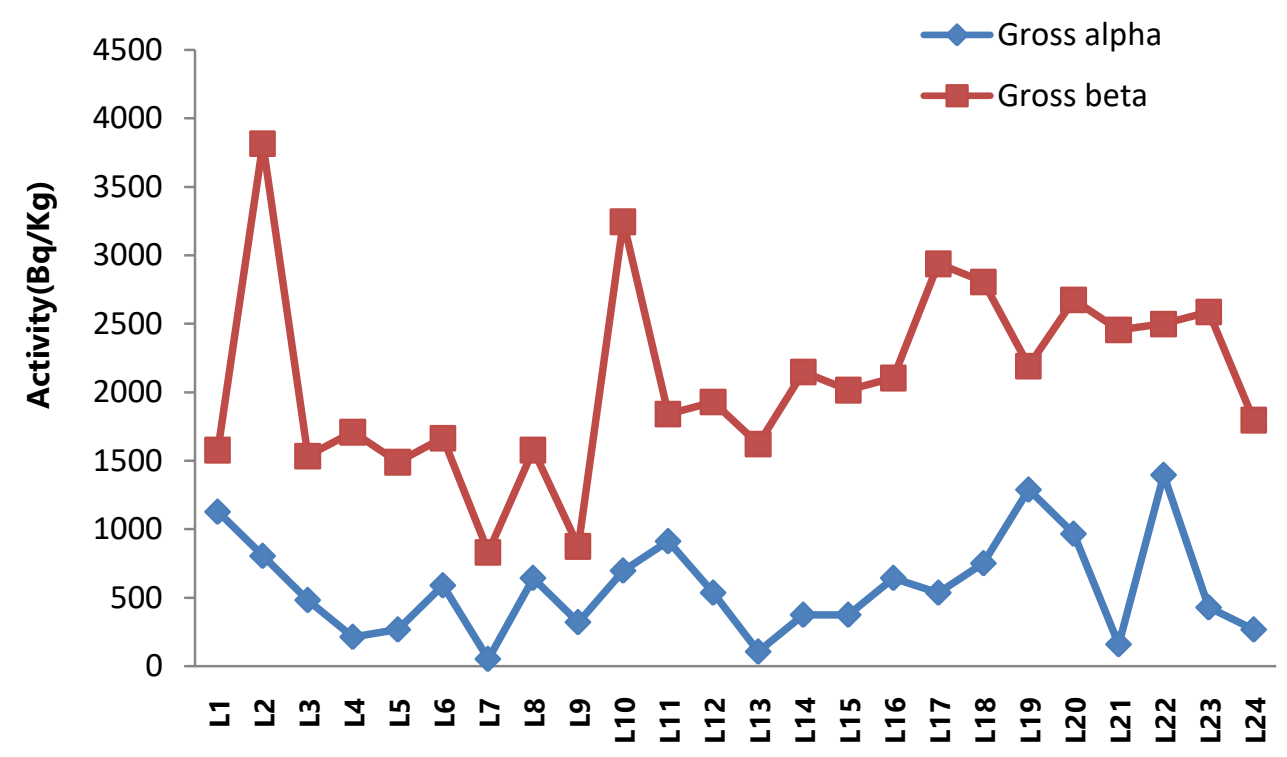

Sample Location

\section{Fig 2: Gross alpha and gross beta activities for various places}

The gross alpha activity of the rock samples collected from Western Ghats in Kanyakumari district were measured and tabulated in table.1. The gross alpha activities vary from lower value (53.76 $\mathrm{Bq} / \mathrm{Kg}$ ) was observed in $\mathrm{L} 7$ to higher value $(1397.85 \mathrm{~Bq} / \mathrm{Kg})$ was observed in L22 with an average of $582.44 \mathrm{~Bq} / \mathrm{Kg}$.

The gross beta activity was maximum at $\mathrm{L} 2(3815.79 \mathrm{~Bq} / \mathrm{Kg})$, while it is minimum at L7 $(833.33 \mathrm{~Bq} / \mathrm{kg}$ ) with an average of $2081.51 \mathrm{~Bq} / \mathrm{Kg}$. The higher value of beta activity in $\mathrm{L} 2$ is due to the presence of ${ }^{40} \mathrm{~K}$, which is the natural beta emitter. The graph shows the random distribution of radionuclides which are emitting alpha and beta radiation. Some locations have higher activity whereas some places have very low activity. 


\section{CONCLUSION}

In the present study, the graph shows that, the gross alpha and beta activities are randomly distributed in Western Ghats in Kanyakumari district. The gross alpha activity values varied from $53.76 \mathrm{~Bq} / \mathrm{Kg}$ to $1397.85 \mathrm{~Bq} / \mathrm{Kg}$ with an average of $582.44 \mathrm{~Bq} / \mathrm{Kg}$, whereas the gross beta activity values varied from $833.33 \mathrm{~Bq} / \mathrm{Kg}$ to $3815.79 \mathrm{~Bq} / \mathrm{Kg}$ with an average of $2081.51 \mathrm{~Bq} / \mathrm{Kg}$. From these results the gross beta activity is higher than the gross alpha activity in the collected rock samples. Hence this study will helps to prepare the baseline data for gross alpha and gross beta radioactivity in rock sample which will be used as finger print for the comparison of radioactivity level.

\section{REFERENCES}

1. Biswas. S, Ferdous. J, Begum. A, Ferdous. N. (2015). Study of Gross Alpha and Gross Beta Radio activities in Environmental Samples. J.Sci.Res. 7(1-2), 35-44.

2. Rajesh. P, Joseph Vedhagri. S, Ramasmy.V, Meenakshisundaram. V. (2013). Measurement of level of natural gamma emitting radionuclides in charnockite rocks of Kalrayan Hills, India. Archives of Applied Science Research. 5(2), 279-286.

3. Manigandan. P.K, Chandra Shekar. B. (2014). Evaluation of Radionuclides in the Terrestrial Environment of Western Ghats. Journal of Radiation Research and Applied Sciences. 7, 310-316.

4. UNSCEAR .(2000).Sources of biological effects of ionizing radiation. Report to general assembly with scientific annexes. New York: United States.

5. Brug.W.P. (1997). Laboratory Method for Gross Alpha and Beta activity Determination (Los Alamos National Laboratory, Llos Alamos, New Mexico.

6. Manual MPC-2000, Gross Alpha /Beta Counter (Protean Instrument Corporation).

7. Shanthi. G, Manian. C.G, Allan Gnana Raj. G, Thambi Thanka Kumaran.T. (2009). Radioactivity in Food Crops from High Background Radiation Area in Southwest India. Current Science. 97, 9.

8. Ragel Mabel Saroja. R. (2008). High Background Radiation Sweeping Along the Southwest Coast of Tamilnadu, India. Current Science. 94, 10.

9. Narayana. Y, Rajasshekara. KM, Siddappa. K. (2007). Natural Radioactivity n some major Rivers of Coastal Karnataka on the Southwest Coast of India. Journal of Environmental Radioactivity. 95, 98-106. 